\title{
The Use of Adipose Stem Cells in Cranial Facial Surgery
}

\author{
Michelle Griffin • Deepak M. Kalaskar • Peter E. Butler • \\ Alexander M. Seifalian
}

Published online: 10 June 2014

(C) The Author(s) 2014. This article is published with open access at Springerlink.com

\begin{abstract}
Craniofacial malformations, have devastating psychosocial implications for many adults and children and causes huge socioeconomic burden. Currently craniofacial defects require soft tissue transfer, bone grafting techniques or difficult procedures such as microvascular free flaps. Such tissues are often limited in quantity, their harvest causes secondary large donor site defects and they lack the capability to fully restore previous form and function. Stem cell technology is being utilised for various tissue and organs of the body and consequently surgeons are eager to transfer these principles for craniofacial surgery. Adipose derived stem cells (ADSCs) are an exciting stem cell source for craniofacial surgeons due to their easy and painless isolation, relatively large abundance and familiarity with the harvesting procedure. ADSCs also have multiple desirable properties including adipogenic, osteogenic and chondrogenic potential, enhancement of angiogenesis and immunodulatory function. Due to these advantageous characteristics, ASDCs have been explored to repair craniofacial bone, soft tissue and cartilage. The desirable characteristics of ADSCs for craniofacial surgical applications will be explained. We report the experimental and clinical studies that have explored the use of ADSCs for bone, cartilage and soft tissue craniofacial defects. We conclude by establishing the key questions that are preventing the clinical application of ADSCs for craniofacial surgery.
\end{abstract}

Keywords Cranial facial surgery $\cdot$ Adipose derived stem cells · Osteogenesis · Chondrogenesis · Adipogenesis

M. Griffin • D. M. Kalaskar • P. E. Butler • A. M. Seifalian $(\triangle)$

UCL Centre for Nanotechnology and Regenerative Medicine, Division of Surgery \& Interventional Science, University College London, London, United Kingdom

e-mail: a.seifalian@ucl.ac.uk

P. E. Butler • A. M. Seifalian

Royal Free London NHS, Foundation Trust Hospital, London, United Kingdom

\section{Introduction}

As the field of regenerative medicine continues to grow, there is a need for a reliable and continuous source of stem cells that can be easily obtained. Mesenchymal stem cells can be isolated from various tissue sources in adults [1]. For many years, bone marrow derived stem cells (BMDSCs) have been the focus of tissue engineering research strategies. However, current research interest is looking towards developing adipose derived stem cells (ADSCs), which are isolated directly from either fat excision or liposuction during plastic surgical procedures. ADSCs share many properties as those of BMDSCs with similar potential to differentiate into bone, cartilage, muscle and fat [2]. However, with easier isolation and better availability ADSCs have sparked great clinical and research interest. There have already been several clinical reports of the successful application of ADSCs including soft tissue augmentation [3], wound healing [4] and Crohn's disease [5].

Craniofacial surgery is particularly suited to the implementation of ADSCs due to the huge demand for reconstruction of several tissue types. Firstly, there is a huge demand for soft tissue reconstruction including (1) reconstruction of surgically or traumatically created facial tissue voids (2) to restore bulk of aging tissue in order to correct soft tissue folds (3) to augment or create soft tissue for cosmetic enhancement and lastly (4) to create soft tissue contours for patients with congenital soft tissue deficiencies. Secondly, there is strong clinical need to generate bone for craniofacial osseous defects due to congenital diseases, trauma and surgically created bony defects following cancer resections. The paediatric population represents a large clinical need for tissue-engineered bone including cleft palate, Down syndrome, Treacher Collins syndrome and Apert and Crouzon syndromes. Autogenous bone grafts harvested from the iliac bone are considered to be the gold standard to treat bone defects but this causes huge donor site morbidity, pain and has limited availability. Calvarium defects represent a particular reconstructive challenge as above the age of 2 years it does not regenerate on its own 
[6]. Lastly cartilage is often required following trauma, inflammatory conditions or cancer resections of the nasal area or in paediatric patients for auricular reconstruction due to microtia and anotia.

The "gold standard" to address these defects currently involves using autologous material in the form of soft tissue transfer, bone or cartilage grafting and complicated free flaps and microvascular anastomosis $[7,8]$. Such techniques create secondary donor defects with associated risks and complications and are limited in their availability. Various alloplastic materials are available to replace autologous tissue including silicone, medpor, titanium but all have shown mechanical failure, extrusion, infection and limited capability to recreate previous form [9-11]. It has been suggested that ADSC strategies can overcome the necessary donor site morbidity, limited availability and failure of autologous grafts and extrusion and infection of alloplastic grafts $[12,13]$. Various techniques for using ADSCs for clinical applications are shown in Fig. 1.

This review aims to describe the desirable properties of ADSCs currently in practice. Further, we evaluate the evidence that uses ADSCs for bone, cartilage and adipose engineering currently in practice for craniofacial reconstruction surgery and lastly describe the possibilities and expected contribution of ADSCs in the future of craniofacial surgery.

\section{What are Adipose Stem Cells?}

Adipose tissue is one of the largest tissues in the body, acting as an important energy and endocrine reservoir [14]. Adipose tissue is mainly composed of adipocytes (fat cells), accounting for more than $90 \%$ of the tissue volume, being arranged in lobules [15]. Adipose tissue is a very vascular tissue with all of

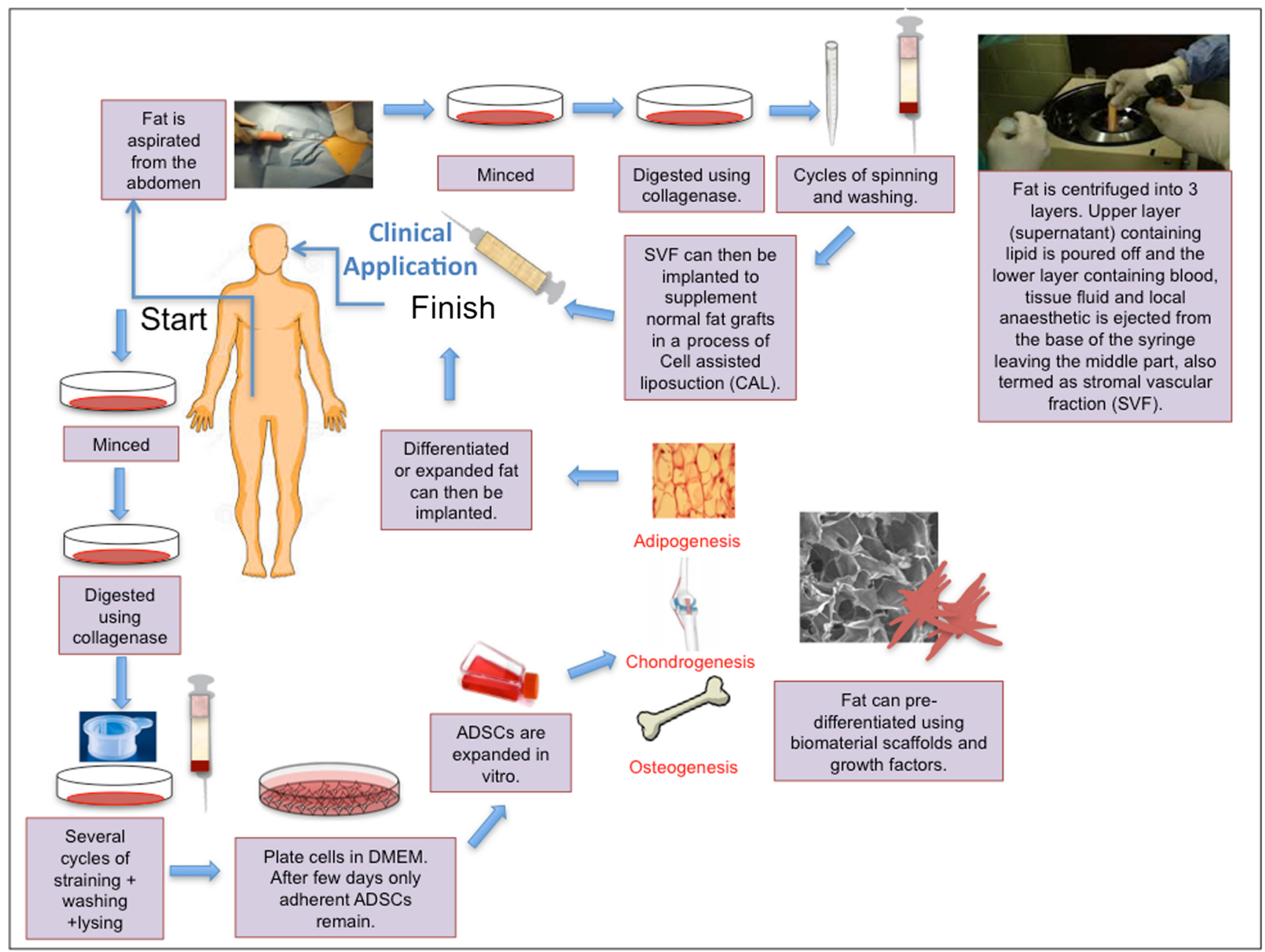

Fig. 1 Schematic drawing illustrating how adipose stem cells can be utilised for craniofacial surgery. Adipose derived stem cells (ADSCs) can supplement fat grafts for improved adipogenesis in a process called cell assisted liposuction (CAL). Furthermore, ADSCs can be expanded in vitro under Good Manufacturing Practice and Good Laboratory
Practice before clinical use. Lastly ADSCs inserted on biomaterials with/without growth factors is being explored to enhance their differentiation towards certain cell lineages. ADSCs; Adipose derived stem cells. DMEM; Dulbecco Modified Eagle Medium 
the adipocytes in contact with the surrounding capillaries [14]. In addition to the adipocytes, adipose tissue consists of pericytes, fibroblasts, macrophages, vascular endothelial cells and an extracellular matrix [15]. ADSCs were first identified in 2001 by Zuck et al. as a population of fibroblast cells capable of differentiating into adipogenic, chondrogenic, myogenic and osteogenic cells in the presence of specific induction factors [2]. Since this time many groups have tried to optimise the isolation and expansion of ADSCs [16-27]. ADSC are commonly extracted from adipose tissue in a multistep wise procedure. Adipose tissue is first obtained through liposuction, from a variety of sites including the upper arm, medial thigh, trochanteric, and superficial deep abdominal depots [21]. The most commonly used ADSC isolation technique is that described by Coleman. Processing the lipoaspirate via the Coleman method involves centrifugation of lipoaspirate at 3,000 rpm for $3 \mathrm{~min}$ in $10 \mathrm{ml}$ syringes. The processed harvested fat is then separated into three layers. The upper layer (supranatant) containing lipid is poured off and the lower layer containing blood, tissue fluid and local anaesthetic is ejected from the base of the syringe leaving the middle part containing stromal cells, vascular endothelial and mural cells, termed the stromal vascular fraction (SVF). To isolate ADSCs from the adipose tissue, it is common to digest the adipose tissue using collagenase after mincing and cutting of the tissue. After neutralisation with Dulbecco Modified Eagle Medium (DMEM) containing foetal bovine serum (FBS) and centrifugation an ADSC-rich pellet is formed. This is then cultured and expanded in media. Following a period of several days or hours the non-adherent cells are then removed with the remaining cells being ADSCs [27] (Fig. 1).

\section{Useful Properties of Adipose Stem Cells}

Human adipose tissue offers several advantages as a stem cell source (Table 1). With the widespread obesity in current populations, most adults have abundant adipose tissue [28]. In addition, the technique described in Fig. 1 for adipose harvesting is relatively less painful compared to the bone marrow aspiration with decreased donor site morbidity and 10-100 times greater frequency of stromal cells per unit volume [29]. ADSCs are attractive options for tissue regeneration due to their angiogenic, wound healing and immunodulatory properties [30-45].

\section{Current Evidence Supporting the Use of ADSCs for Craniofacial Surgery}

ADSCs are an exciting stem cell source for craniofacial surgeons due to the capacity to facilitate angiogenesis, limit apoptosis, provide immunodulatory function and multi- differentiation capacity. Preclinical and clinical trials are already exploring the potential of ADSCs for reconstructive surgery. For craniofacial surgery bone, cartilage, fat tissues are required for various reconstructive applications. This section will discuss each of these requirements in detail.

\section{Use of ADSCs to Generate Bone}

ADSCs can undergo osteogenic differentiation in vitro by exposure to a combination of ascorbate, $\beta$-glycerophosphate, various bone morphogenetic proteins (BMPs), dexamethasone, and/or vitamin D3, confirming bone formation using Alizarin Red or Von Kossa staining, usually over a two-week period [45]. Several studies have shown that ADSCs will express multiple markers for osteogenesis in these conditions including cbfa-1, alkaline phosphatase, osteopontin, osteocalcin and collagen I [46, 47].

Repair of large bone defects is a common challenge to craniofacial reconstructive surgeons. The current gold standard of current restoration is to use autologous bone to reconstruct craniofacial defects, which is often insufficient in quantity and causes huge donor site morbidity. Despite alloplastic materials and prosthetic implants including metal and plastics trying to act as alternatives, optimal clinical results are not achieved for cranial restoration. However, by delivering osteogenic induced cells or cells capable of osteogenesis such as ADSCs, bone formation for cranial bone defects could be achieved. Several pre-clinical studies have utilised ADSCs for engineering bone to repair cranial defects and few clinical cases have also been reported.

Calvarial defects are the more frequently used model to test stem cells for tissue engineering. Several rodent animal studies have illustrated the ability of ADSCs to form bone to heal calvarial defects. Human ADSCs isolated from the fat tissue of 3 patients was harvested from the abdominal tissue discarded during reconstructive breast surgery. The ADSCs were then seeded on polylactic glycolic acid, atelocollagen, and hydroxyapatite scaffolds to support osteogenesis in athymic nude rat calvaria [48]. Bone mineral densitometry analysis revealed a 2 to 3 -fold increase in mineral density in ADSC-seeded scaffolds and healed the rat calvarial defects [48]. Osteogenically induced ADSCs have been thought to provide better bone formation than unstimulated ADCSs. Di bella et al. highlighted that osteogenically induced ADSCs can promote more bone formation than unstimulated ADSCs in a rabbit model. Osteogenically induced ADSCs seeded on fibronectin treated Poly(lactic acid) (PLA) scaffolds formed significantly more bone than PLA scaffolds without fibronectin and scaffolds with undifferentiated ADSCs $(p<0.0005)$ over 6 weeks [49]. The immunomodulatory functions of allogenic ADSCs has been utilised by healing a cranial critical sized defect without the need of immunosuppressive therapy on a coral scaffold [50]. 


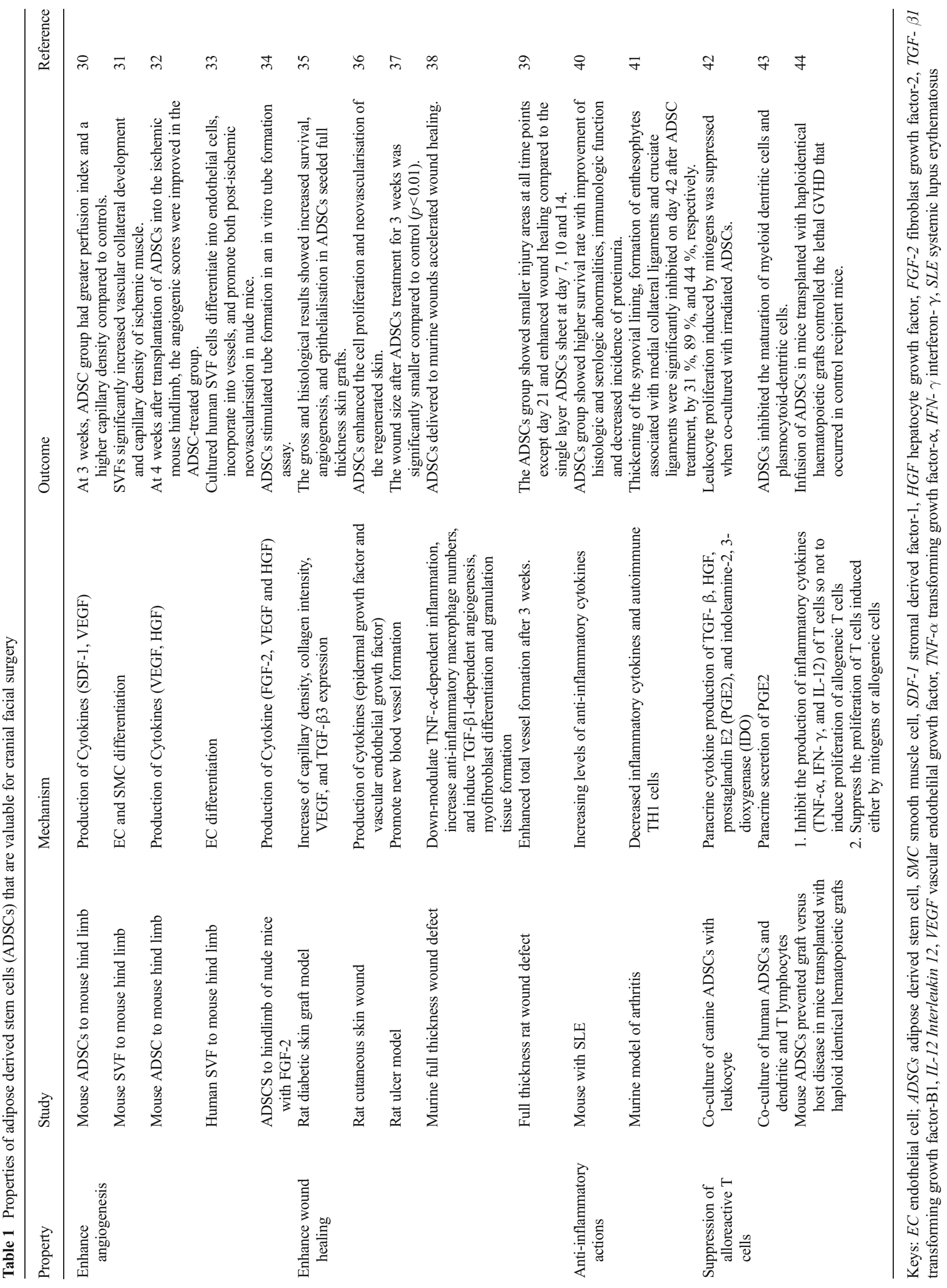


Few studies, have illustrated that the combination of growth factors and ADSCs can support the healing of calvarial bone defects. Xenograft bone chips, covered with acellular periosteum with ADSC and progenitor stem cells and vascular endothelial growth factor and/or bone morphogenetic protein2 (BMP-2) showed histological confirmation of bone healing for rat critical calvarial bone defects.[51] Lin et al. showed that BMP-2 transfected ADSCs loaded on alginate showed complete healing of rat calvarial cranial defects of 16 weeks but only partial repair for scaffold alone and non transfected ADSCs [52]. Lin et al. illustrated that osteogenic differentiation by BMP-4 adenovirus of BMDSCs and ADSCs was capable of healing rabbit calvarial defects [53].

Whilst there are numerous reports in rodents, there are only two clinical studies showing the capacity of ADSCs for calvarial bone regeneration. The first was the case report of using ADSCs to reconstruct widespread calvarial defects of a 7-year-old girl following a severe head injury [54]. ADSCs were combined with fibrin glue and bone from the iliac crest to reconstruct the calvarial defect in a single operation. The second study, also reported in Germany, illustrated the reconstruction of large calvarial defects in 4 patients using ADSC seeded in beta-tri-calcium phosphate granules [55].

Several large animal studies have illustrated the potential of ADSCs to healing mandibular defects. The injection of ADSCs into the ramus of the pig mandible showed accelerated bone development after 2 and 4 weeks [56]. Similarly, ADSCs seeded onto collatemp scaffolds (collagen impregnated with gentamycin) showed greater bone formation than scaffold alone in a canine mandibular defect [57]. Two clinical studies have confirmed the used of ADSCs for mandible defects. ADCS have been used to reconstruct the critical size defects of the mandible seeded on a resorbable scaffold combined with BMP-2 in 23 patients [58]. More recently, the same author reported the reconstruction of a $10 \mathrm{~cm}$ anterior mandibular ameloblastoma resection defect, using a tissue-engineered construct consisting of $\beta$-tricalcium phosphate $(\beta$-TCP) granules, recombinant human bone morphogenetic protein-2 (BMP-2), and Good Manufacturing Practice (GMP) level autologous ADSCs [59].

The use of ADSCs and orbital floor defects has not been thoroughly explored. A single report has also illustrated the success of ADSCs for orbitozygomatic reconstruction [60]. A 14-year of boy with Treacher Collins Syndrome was treated with engineered bone made from a combination of human bone allograft, ADSCs, BMP-2, and periosteal graft to manage his bilateral orbitozygomatic defects (Fig. 2) [60]. Similarly there has been one single case report of using ADSCs for maxillary reconstruction (Fig. 2) [61].
Use of ADSCs to Generate Cartilage

Cranial cartilage defects involves the auricular and nasal cartilage caused by congenital deformities, cancer resections, inflammatory conditions and trauma. Adult cartilage is avascular, with limited capability of self-restoration due to the matrix having a slow turnover and very low supply of progenitor cells [62]. Therefore, current restoration of cartilage defects involves obtaining autologous cartilage from either costal, auricular or nasal cartilage. However, the limited supply of cartilage, the consequential donor site morbidity, the fact it cannot be easily shaped into the desired shape, are all reasons that researchers are trying to find alternative strategies to create cartilage tissue [62]. Since the work of Cao et al. in 1997, who engineered cartilage using chondrocytes in the shape of an ear in an nude mouse model, many researchers have tried to develop cartilage constructs using tissue engineering principles [63]. In addition to finding the right scaffolds to support chondrogenesis the source of cells to allow for cartilage formation is required.

The expression of chondrogenic markers can be induced in ADSCs in vitro after exposure to a combination of dexamethasone, transforming growth factor (TGF $\beta-1 / \beta-3$ ) and ascorbate confirmed by positive alician blue staining over a threeweek period [62]. Several studies have highlighted that 3dimensional culture (3D) enhanced the chondrogenic differentiation of ADSCs compared to 2-dimensional (2D) culture. The simplest method to achieve this is to culture using a micromass pellet [64]. Alternatively, ADSCs can be seeded on a biomaterial scaffold grown in chondrogenic culture condition. Yoon et al. illustrated that ADSCs showed greater proliferation and differentiation on 3D-hydroxyapatite scaffolds compared to the micromass culture [65].

Several culture medium cocktails have been investigated to induce chondrogenesis of ADSCs and BMDSCs, due to the difficulty to obtain reliable differentiation (Table 2) [66-75]. In addition to the media, several biomaterials have successfully shown to support the differentiation of ASDSCs into cartilage. Natural biomaterials that support chondrogenesis include alginate and fibrin. Autologous ADSCs were isolated and induced with growth medium and placed in a fibrin glue scaffold and into $3 \times$ 4-mm full-thickness chondral defects in rabbits with negative controls. Twelve of 12 (100\%) articular surface defects containing tissue-engineered stem cell constructs healed with hyaline-like cartilage, versus 1 of 12 $(8 \%)$ in the control group $(p<0.001)$ [76]. Similarly, alginate disks seeded with ADSCs supported the formation of a cartilaginous like matrix at 12 weeks in nude mice, with increase expression of collagen III, VI and chondroitin sulphate [77].

Several synthetic scaffolds have been utilised for the chondrogenic differentiation of ADSCs. Cui et al. found that PGA scaffolds supported chondrogenesis of ADSCs to repair full thickness articular cartilage defects $(8 \mathrm{~mm}$ in diameter, 


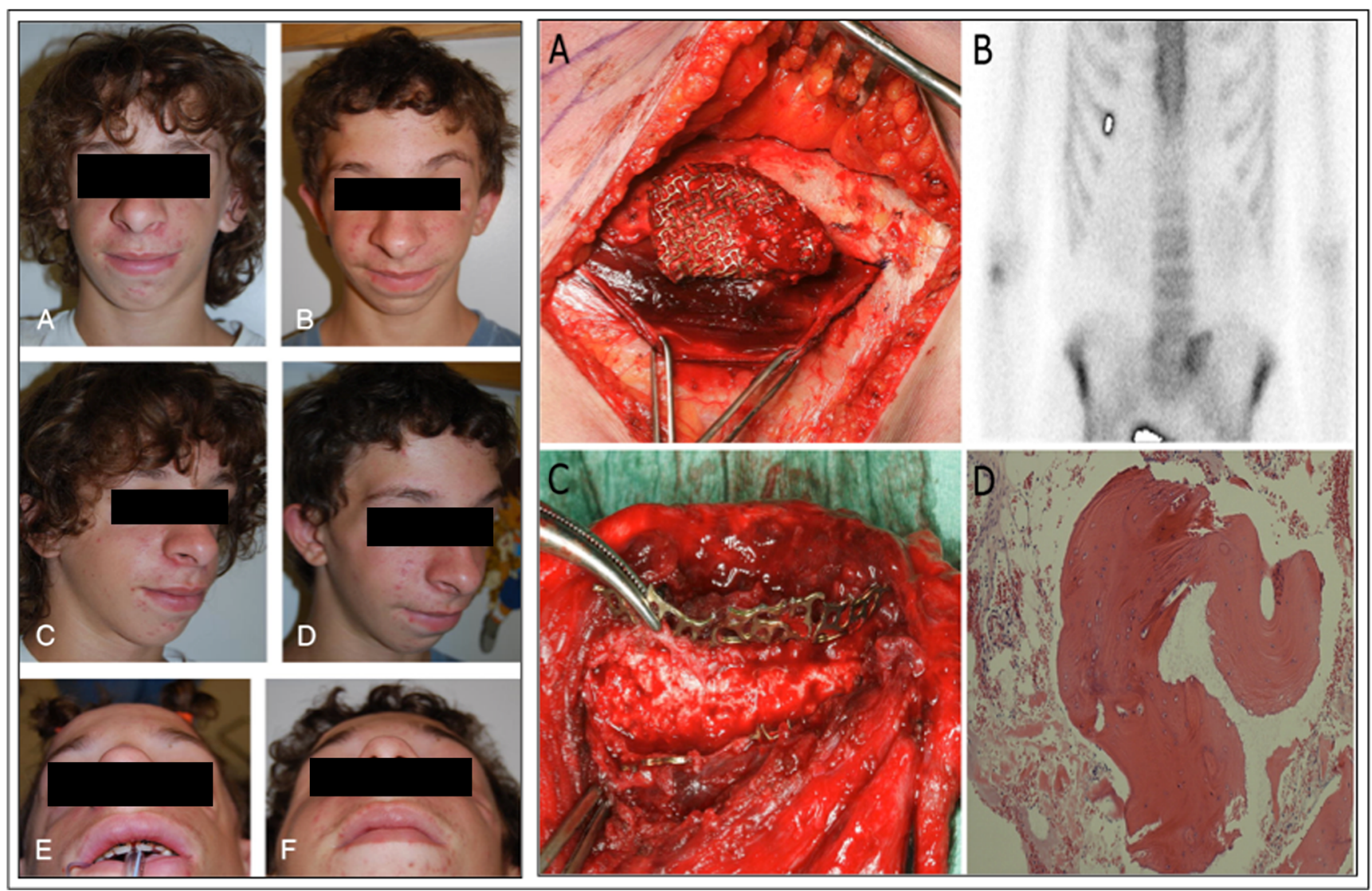

Fig. 2 Left: 14-year of boy with Treacher Collins Syndrome treated with human bone allograft, adipose derived stem cells (ADSCs), bone morphogenetic protine-2 (BMP-2) and a periosteal graft to manage his bilateral orbitozygomatic defects. a, c, e Preoperative views. b, d, f postoperative views [60]. Reprinted from Taylor JA. (2010). Bilateral orbitozygomatic reconstruction with tissue-engineered bone. J Craniofac Surg, 21, 1612-4. Right: Maxillary reconstruction following hemimaxillectomy using ADSCs seeded on a titanium cage with beta-tricalcium phosphate (bTCP). (a) The titanium cage filled with bTCP and ADSCs, before being inserted into the rectus abdominis muscle pouch [61]. b Skeletal scintigraphy of the rectus abdominis muscle was performed which confirmed bone activity

deep to subchondral bone) in femur trochlea at 3 months [78]. Poly-lactide-co-glycolide (PLGA) scaffolds were also found to support the differentiation of ADSCs for 3 weeks in vitro in media supplemented with TGF- $\beta 1$ [79].

Few studies have compared differentiated and undifferentiated ADSCs for their chondrogenic potential. Rabbit osteochondral defects were treated with predifferentiated and undifferentiated ADSCs on gelatin hydrogels. Predifferentiated ADSCs showed the highest level of cartilage formation by histological examination. Predifferentiated ADSCs were further compared to undifferentiated ADSCs after being implanted into nude mice on poly(3hydroxybutrate-co-3-hydroxyvalerate) (PHBV) scaffolds for 16 weeks [80]. Differentiated ADSCs were found to show stronger chondrocytes-specific histochemical staining and stronger compression moduli [80]. Alginate gels also supported cartilage formation when ADSCs were pre-differentiated
[61]. c When the rectus abdominis free-flap was raised, and the muscle pouch and titanium cage was opened the tissue engineered bone was clinically confirmed to be rigid. After disconnecting the vessels the flaps was placed in the maxillary defect. [61] d A histological section from the tissue-engineered bone showed normal mature bone structures. Reprinted from Mesimäki K, Lindroos B, Törnwall J, Mauno J, Lindqvist C, Kontio R, Miettinen S, Suuronen R. (2009). Novel maxillary reconstruction with ectopic bone formation by GMP adipose stem cells. Int J Oral Maxillofac Surg, 38, 201-9 Copyright (2014), with permission from Elsevier

when subcutaneously implanted into nude mice after 20 weeks but no cartilage like tissue formation was found using undifferentiated ADSCs [81].

Despite extensive research into the chondrogenic potential of ADSCs only one in vivo study has confirmed the promising application of ADSCs for craniofacial applications. Bahrini et al. recently illustrated that ADSCs may be a novel candidate for the repair of auricular cartilage injuries in vivo. ADSCs from rabbit adipose tissue was injected into the midportion of a surgically created rabbit ear auricle cartilage defect. After 6 months mature cartilaginous plates completely filled the defect in the native cartilage [82].

It is clear that the biochemical environment, including the growth factors, hormones and specific laboratory cell culture conditions required to chondrogenic differentiate ADSCs is still being determined. Hence, further exploration into optimising chondrocyte culture conditions is required 
Table 2 Examples of the multiple medium combinations to stimulate chondrogenic differentiation of adipose derived stem cells (Adapted from 66) Source of tissue were from human except * from rabbit

\begin{tabular}{|c|c|c|}
\hline Year and Ref & Differentiation Protocol & Outcome \\
\hline $2001[2]$ & DMEM, FBS, insulin, ascorbate 2-phosphate & $\begin{array}{l}\text { Processed lipoaspirate cells differentiate in vitro into a chondrogenic } \\
\text { lineage using specific induction factors. }\end{array}$ \\
\hline $2002[67]$ & $\begin{array}{l}\text { DMEM, FBS, ITS, ascorbate 2-phosphate, } \\
\text { dexamethasone, TGF } \beta-1 \text {, sodium pyruvate }\end{array}$ & $\begin{array}{l}\text { ADSCs abundantly synthesized cartilage matrix molecules including } \\
\text { collagen type II, VI, and chondroitin 4-sulfate. }\end{array}$ \\
\hline $2003[68]$ & $\begin{array}{l}\text { DMEM, BSA, ITS, ascorbate 2-phosphate, } \\
\text { sodium pyruvate, TGF } \beta-1 \text {, dexamethasone, } \\
\text { L-glutamine, pyridoxine hydrochloride }\end{array}$ & $\begin{array}{l}\text { The combination of TGF- } \beta 1 \text { and ITS stimulated cell growth and } \\
\text { synthesis of proteins and proteoglycans by human ADSCs. }\end{array}$ \\
\hline 2004 [69] & $\begin{array}{l}\text { DMEM, FBS, ITS, ascorbate 2-phosphate, } \\
\text { dexamethasone, TGF } \beta-1\end{array}$ & $\begin{array}{l}\text { Chondrogenic media containing TGF- } \beta 1 \text { significantly increased } \\
\text { protein and proteoglycan synthesis and DNA, sulfated } \\
\text { glycosaminoglycans, and hydroxyproline content of engineered } \\
\text { constructs. }\end{array}$ \\
\hline $2004[70]$ & $\begin{array}{l}\text { DMEM, FBS, transferrin, ITS, ascorbate } \\
\text { 2-phosphate, dexamethasone, TGF } \beta-1\end{array}$ & $\begin{array}{l}\text { Chondrogenic media enabled processed lipoaspirate cells to form } \\
\text { nodules within } 48 \mathrm{~h} \text { of induction and expressed the cartilaginous } \\
\text { markers collagen type II, chondroitin-4-sulfate and keratan sulfate. }\end{array}$ \\
\hline $2006[71]$ & $\begin{array}{l}\text { HAMS-F12, DMEM, ITS, ascorbate 2-phosphate, } \\
\text { dexamethasone and TGF } \beta-1\end{array}$ & $\begin{array}{l}\text { By day } 14 \text { ADSCs in chondrogenic media on elastin hydrogels } \\
\text { exhibited formation of collagen and sulfated glycosaminoglycan. }\end{array}$ \\
\hline $2006[72]$ & DMEM, FBS, ITS, ascorbate 2-phosphate, BMP-6 & $\begin{array}{l}\text { BMP-6 up-regulated aggrecan and collagen expression showing } \\
\text { BMP-6 is an inducer of chondrogenesis in ADSCs. }\end{array}$ \\
\hline $2006[73] *$ & DMEM, FBS, ITS, ascorbate 2-phosphate, BMP-2 & $\begin{array}{l}\text { ADSCs induced by rhBMP- } 2 \text { were transplanted into nude mice and } \\
\text { formed cartilage lacuna at week } 8 \text {. }\end{array}$ \\
\hline $2007[74]$ & $\begin{array}{l}\text { DMEM, ITS, ascorbate 2-phosphate, sodium } \\
\text { pyruvate, pyridoxine hydrochloride, } \\
\text { L-glutamine, dexmethasone, TGF- } \beta 1 \text {, BMP-2 }\end{array}$ & BMP-2 and TGF- $\beta 1$ induced a chondrogenic phenotype in ADSC. \\
\hline 2009 [75] & $\begin{array}{l}\text { HAMS-F12, DMEM, ITS, ascorbate 2-phosphate, } \\
\text { thyroxine, pyruvate, dexamethasone, TGF } \beta-2 \text {, } \\
\text { BMP-2,6,7 }\end{array}$ & $\begin{array}{l}\text { At } 4 \text { weeks, glycosaminoglycan assays, RT-PCR, and histology } \\
\text { demonstrated the combination of } 5 \mathrm{ng} / \mathrm{mL} \text { of TGF } \beta-2 \text { and } \\
100 \mathrm{ng} / \mathrm{mL} \text { of BMP-7 most effectively induced chondrogenesis of } \\
\text { ADSCs. }\end{array}$ \\
\hline
\end{tabular}

Key; TGF $\beta$ - 1 transforming growth factor- $\beta 1, B M P$ bone morphogentic protein, $D M E M$ dulbecco modified eagle medium, $F B S$ fetal bovine serum, $A D S C s$ adipose derived stem cells, ITS insulin-transferrin-selenium, $B S A$ bovine serum albumin, RT-PCR real-time reverse-transcription PCR

before large amount of animal studies or clinical studies are performed.

\section{Use of ADSCs to Generate Adipose}

Soft tissue defects range from a small to major subcutaneous tissue loss on the face from congenial, trauma or inflammatory conditions. Neuber et al. was the first to publish the use of autologous fat transplantation in 1893 for the use of facial scars [83]. Despite adipose tissue being a quick, safe and reliable method for restoring volume and utilised for over 100 years, little has be done to improve the clinical performance of fat grafts. Autologous fat grafts are associated with many difficulties including donor site morbidity, uncertain viability and behaviour of the grafted fat and a low rate of graft survival [84]. The loss of tissue has also been shown to be replaced by the conversion of the graft to fibrous tissue, and sometimes includes the formation of cysts [84]. Recently, ADSCs have been thought to overcome these limitations due to their significant potential for angiogenesis and adipogenesis [85]. When fat is grafted into the site a series of reactions have been found to occur. The bleeding at the recipient tissue activates platelets, causing the release of platelet derived growth factor (PDGF), epidermal growth factor (EGF) and TGF- $\beta[85,86]$. The grafted fat is under severe ischaemia until a direct vascular supply is formed, causing the death of adipocytes, vascular endothelial cells but not adipose-derived stem/progenitor cells $[87,88]$. The dying cells as well as the extracellular matrix (ECM) disruption cause the release of soluble factors. As the ADSCs/progenitor cells do not die they are capable of responding to these factors to release paracrine factors or simulate the mobilisation of endothelial progenitor cells (EPCs) from the bone marrow or resident progenitor cells to stimulate angiogenesis and adipogenesis $[89,90]$ (See Fig. 3). However, further investigation is required to confirm the action of ADSCs in grafted fat tissue to promote angiogenesis and adipogenesis as it is still unclear and not fully understood or documented [85].

Over the last decade several studies have explored the addition of stem cells to fat grafts. Zhu et al. further showed that after 6 and 9 months ADSCs enhanced fat grafts not only enhanced the longevity 2-fold compared to adipose free grafts but enhanced the expression of various growth factors including vacular endothelial growth factor-A (VEGFA) and insulin growth factor-1 (IGF-1), promoting angiogenesis and 


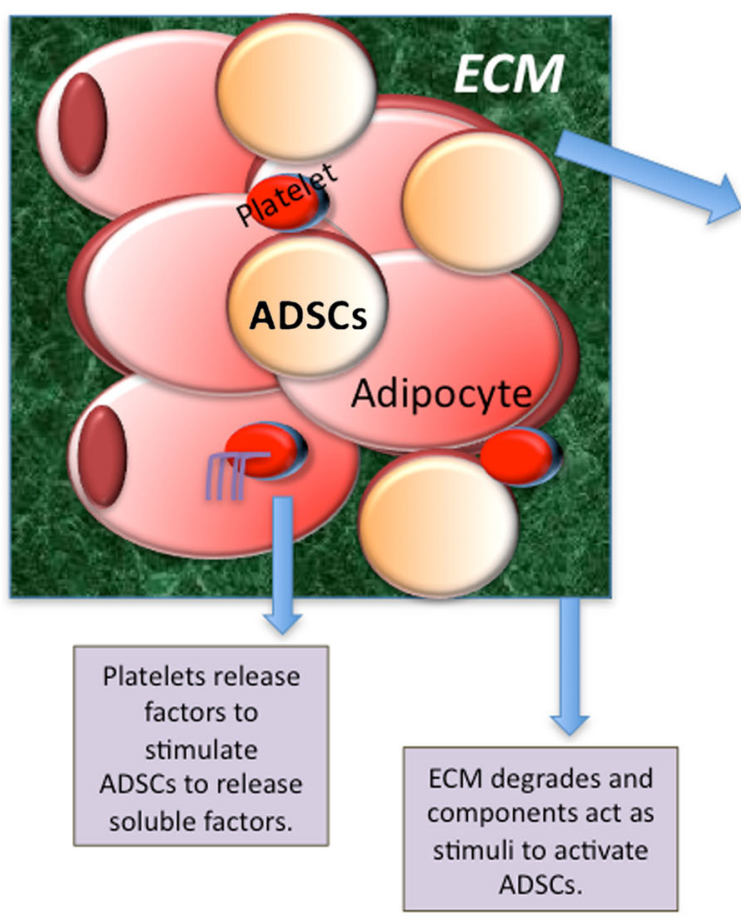

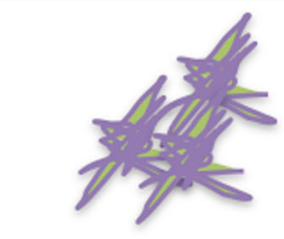

ADSCs release soluble factors in response to hypoxic condition and in response to dying cells and ECM components.

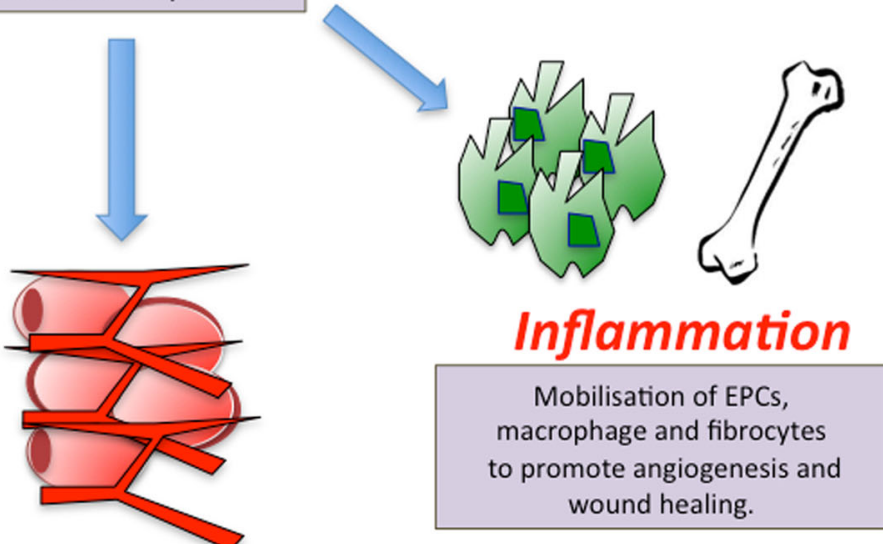

\section{Angiogenesis}

Stimuli promote

angiogenesis.

Fig. 3 Proposed action of adipose derived stem cells (ADSCs) in enhancing survival of fat grafts. Factors released from the extracellular matrix and platelets stimulate ADSCs to secrete angiogenic factors, which stimulate angiogenesis, adipogenesis and wound healing (Adapted from Regenerative Medicine. (2011) 6(6s), 33-41 with permission of Future Medicine Ltd). ECM; Extracellular Matrix, ADSCs: Adipose derived stem cells, EPCs; Endothelial progenitor cells adipocyte differentiation and preventing apoptosis [91]. Moseley et al. illustrated that fat supplemented with ADSCs can improve longevity and the volume of the grafts [92].

In addition, ADSCs have also been used to enhance grafts by using the SVF to augment soft tissue survival, in a process called Cell Assisted Lipotransfer (CAL) (Fig. 1). The process begins with extracting adipose tissue using the conventional machine. The aspirate is then divided into two portions. Half of the aspirate is washed extensively with sterile phosphatebuffered saline (PBS) to remove contaminating debris and red blood cells and then treated with $0.075 \%$ collagenase for $30 \mathrm{~min}$ at room temperature. The infranatant is centrifuged for $5 \mathrm{~min}$ at $1,200 \mathrm{~g}$ after being inactivated using FBS. The cellular pellet is then resuspended in $10 \%$ FBS and passed through a $100-\mu \mathrm{m}$ mesh filter to remove debris. The first portion is then also centrifuged at $1,200 \mathrm{~g}$ for $5 \mathrm{~min}$ and then mixed with the adipose stem cell rich aspirate for $15 \mathrm{~min}$ before being transplanted. Preclinical studies have illustrated the benefit of CAL $[93,94]$. Aspirated fat was transplanted subcutaneously into severe combined immunodeficiency mice with CAL and without CAL. The CAL fat survived better (35\% larger on average) than non-CAL fat, and microvasculature was detected more prominently in CAL fat [93]. The study also confirmed that some of the ADSCs differentiated into vascular endothelial cells being immunopositive for Von Willebrand Factor, which could have contributed to neoangiogenesis in the acute phase of the transplantation [93]. Similarly, Lu et al. reported that fat grafts implanted in the subcutaneous tissue of 18 nude mice supplemented with ADSCs transduced with vascular endothelial growth factor (VEGF) had better survival than ADSCs free fat grafts over 6 months $(74.1 \pm 12.6 \%$ and $60.1 \pm 17.6 \%$, respectively) [94].

Several studies have shown that ADSCs can be delivered to the specific site via scaffolds. ADSCs are capable of attaching to synthetic and natural scaffolds can undergo proliferation, differentiation and angiogenesis. Venugopai et al. illustrated that ADSCs grown on biphasic calcium phosphate allowed the formation of fat when implanted in the rat dorsum muscle 
after 3 weeks [95]. PLGA adipocyte grafts have shown to maintain a phenotype after 56 days with positive confocal microscopy showed associated LipidTOX Deep Red neutral lipid staining. The PLGA scaffolds were further encapsulated within the alginate/chitosan hydrogel capsules and showed subcutaneous tissue over 28 days [96].

Few clinical studies have illustrated the clinical application of ADSCs for clinical use in regeneration of facial fat tissue [84, 97-102]. Yoshimura et al. in 2008 was the first to illustrate the effectiveness of CAL for facial augmentation, in patients with facial lipoatrophy [84]. Lee et al. in 2012 found CAL in 9 patients with facial augmentation gave better satisfaction and photographic evidence of increased volume than those without SVF cells (Fig. 4) [97].

Progressive facial hemiatrophy, also known as ParryRomberg Syndrome, is a gradual loss of the subcutaneous tissue on one side of the face that creates craniofacial asymmetry (Fig. 4) [98]. A single patient underwent CAL after a 5year history of right facial hemiatrophy. At 12 months follow up there was better volume and symmetry of the frontotemporal region and malar prominence and cheek [98]. A similar case report illustrated that ADSCs could be used for Linear scleroderma "en coup de sabre", characterized by atrophy and furrowing of the skin of the front parietal region above the level of the eyebrow [99].

\section{Outlook for Adipose Stem Cell for Cranial Facial Surgery}

Literature reports of ADSCs for cranial factor application have rapidly increased over the last 5 years. Though preclinical data is encouraging, largely level 4 and 5 clinical evidence with lack of power is insignificant to affect tailor clinical practice (Table 3). There are considerable hurdles, which remain to bring ADSCs into large-scale engineering for craniofacial surgery.

There are many unanswered questions that limit the clinical translation of ADSCs for craniofacial application relating to the isolation and processing of ADSCs. Firstly, whether optimal tissue formation is produced using cultured or uncultured

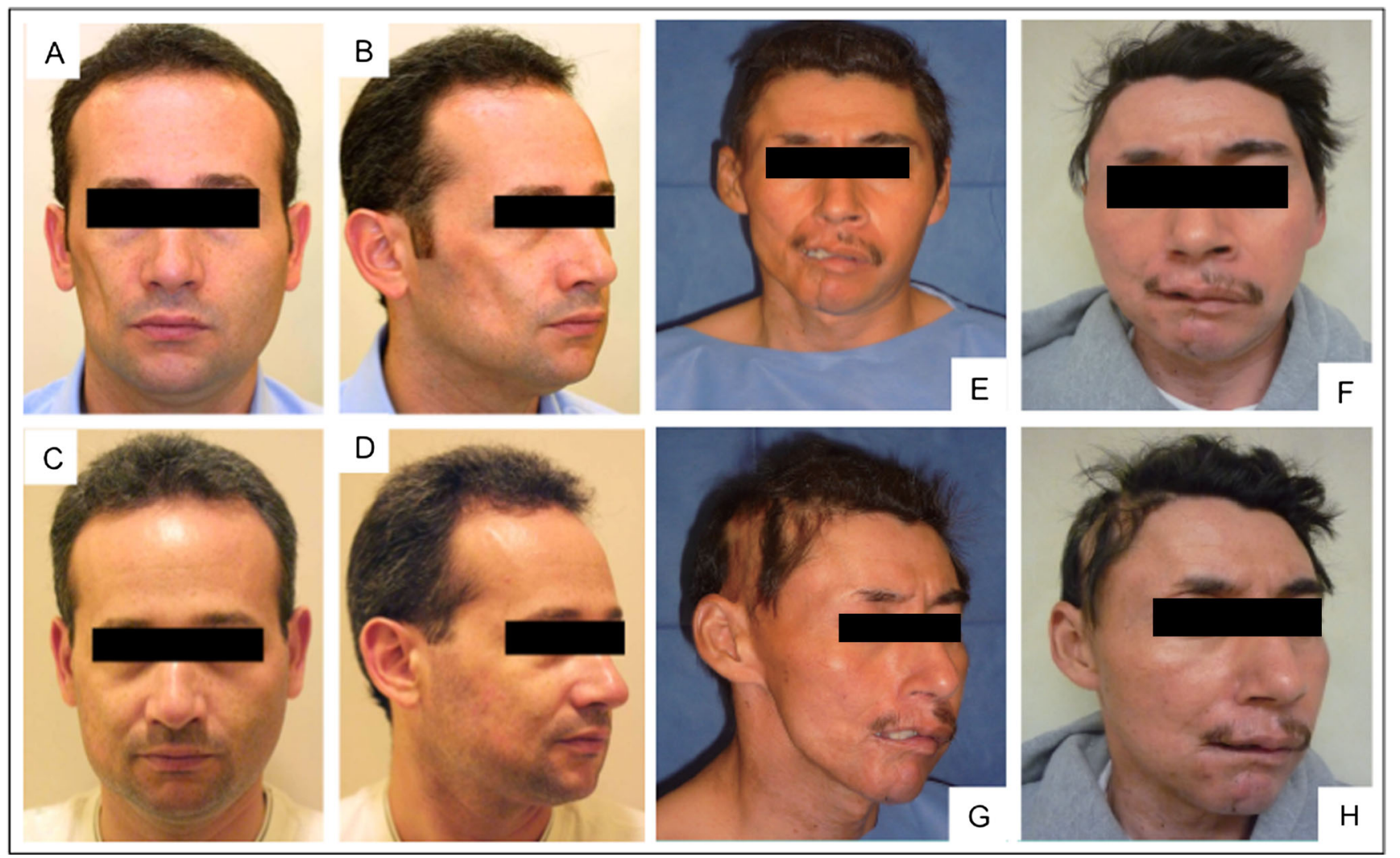

Fig. 4 Left: Clinical views of cell assisted liposuction (CAL) for Grade 4 lipoatrophy. (A, B) Preoperative views of the patient diagnosed with Parry-Romberg syndrome (PRS). (C, D) CAL (110 mL) was performed to correct the facial defect, which improved and the facial contour was maintained at 13-month follow-up. The cheek is soft and natural appearing with no visible scars. Reprinted from Yoshimura K, Sato K, Aoi $\mathrm{N}$ et al. (2008). Cell-assisted lipotransfer for facial lipoatrophy: efficacy of clinical use of adipose-derived stem cells. Dermatol Surg,
34, 1178-85, copyright (2014), with permission of John Wiley \& Sons, Inc. Right: A 35-year-old male patient diagnosed with Parry-Romberg syndrome (PRS). (E,G) Preoperative view. (F, H) Postoperative view 12 months after lipoinjection enriched with adipose derived stem cells. Taken with permission from Castro-Govea Y, De La Garza-Pineda O, Lara-Arias J et al. (2012). Cell-assisted lipotransfer for the treatment of parry-romberg syndrome. Arch Plast Surg, 39, 659-62 


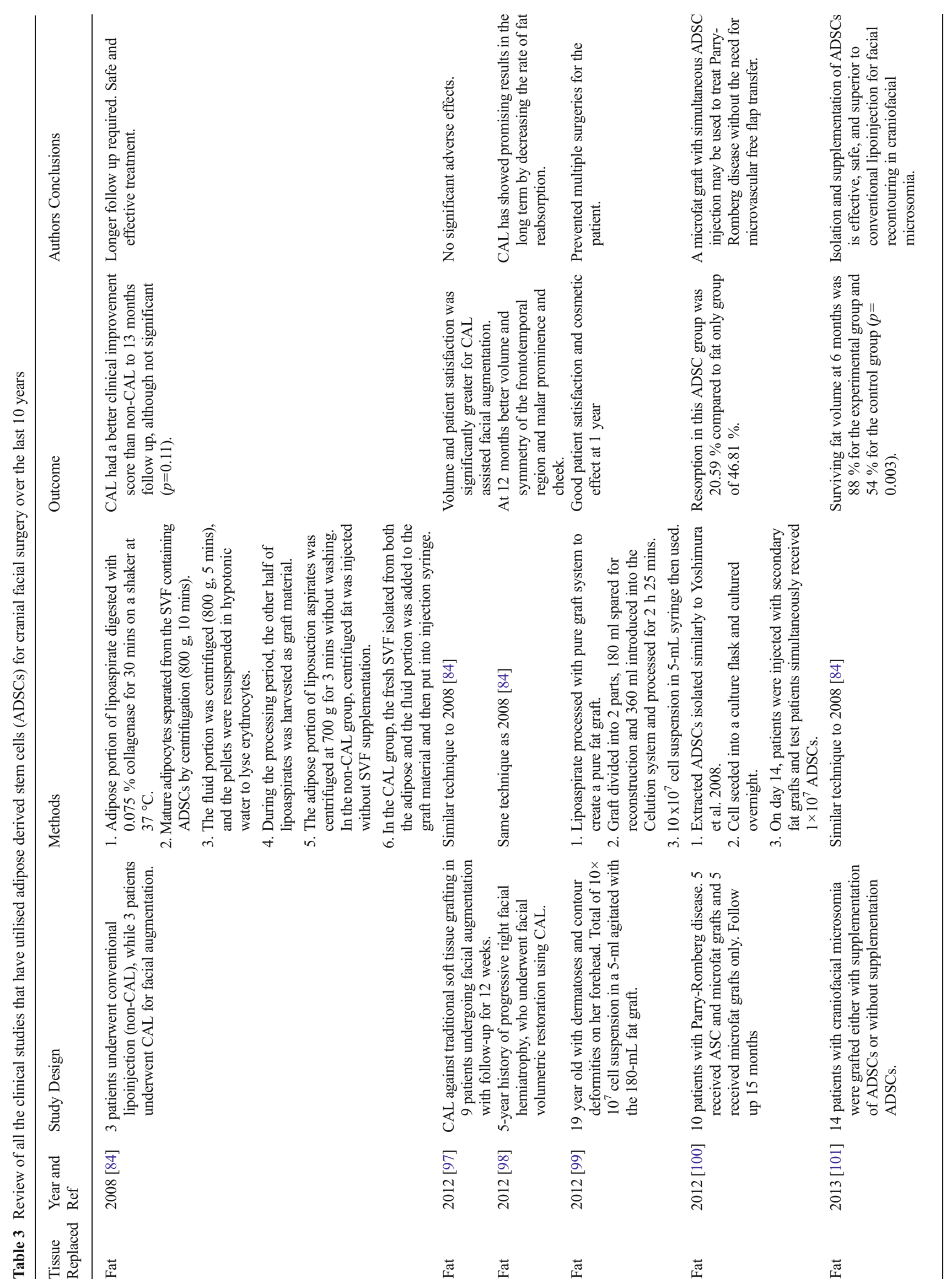




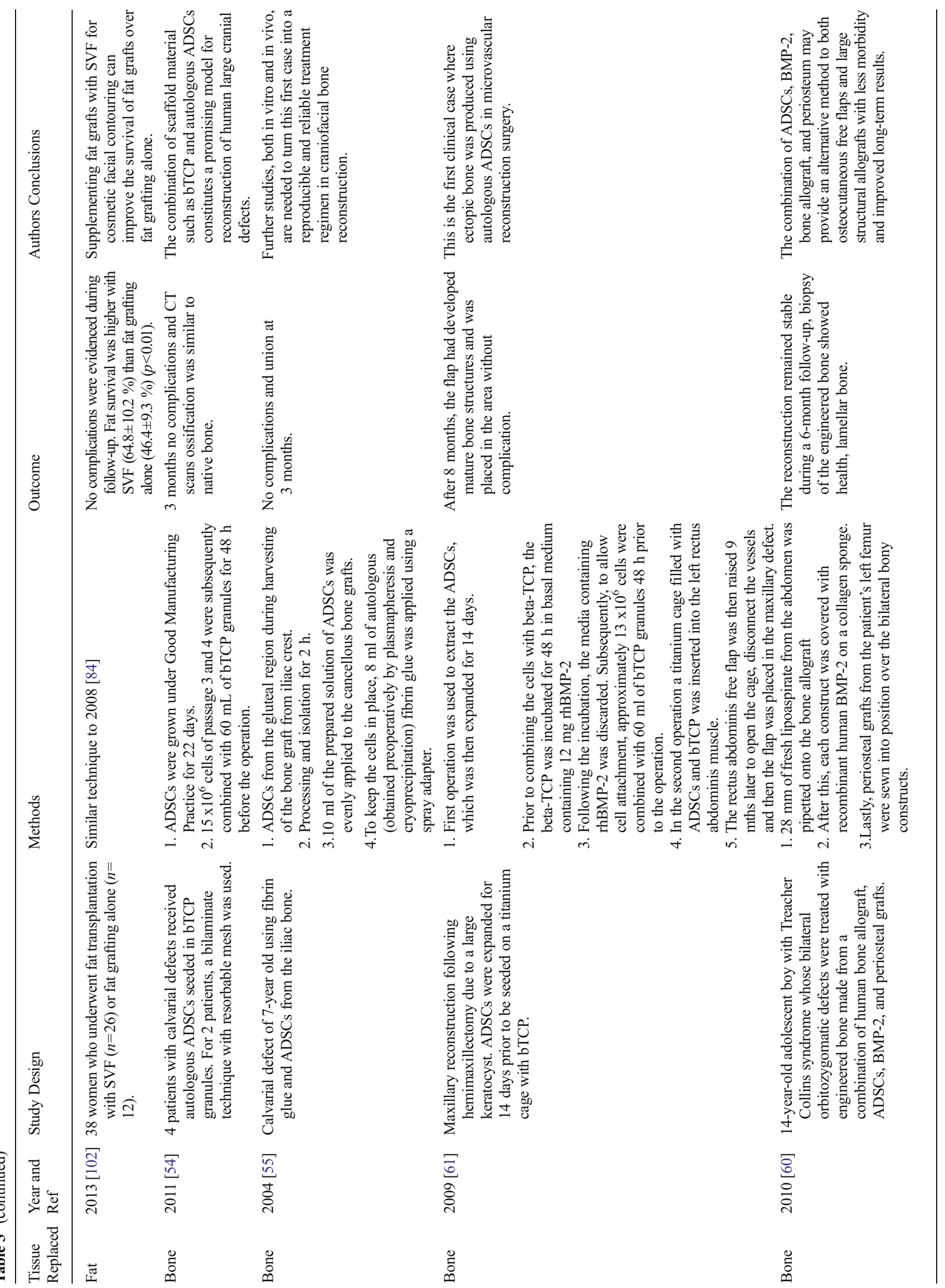




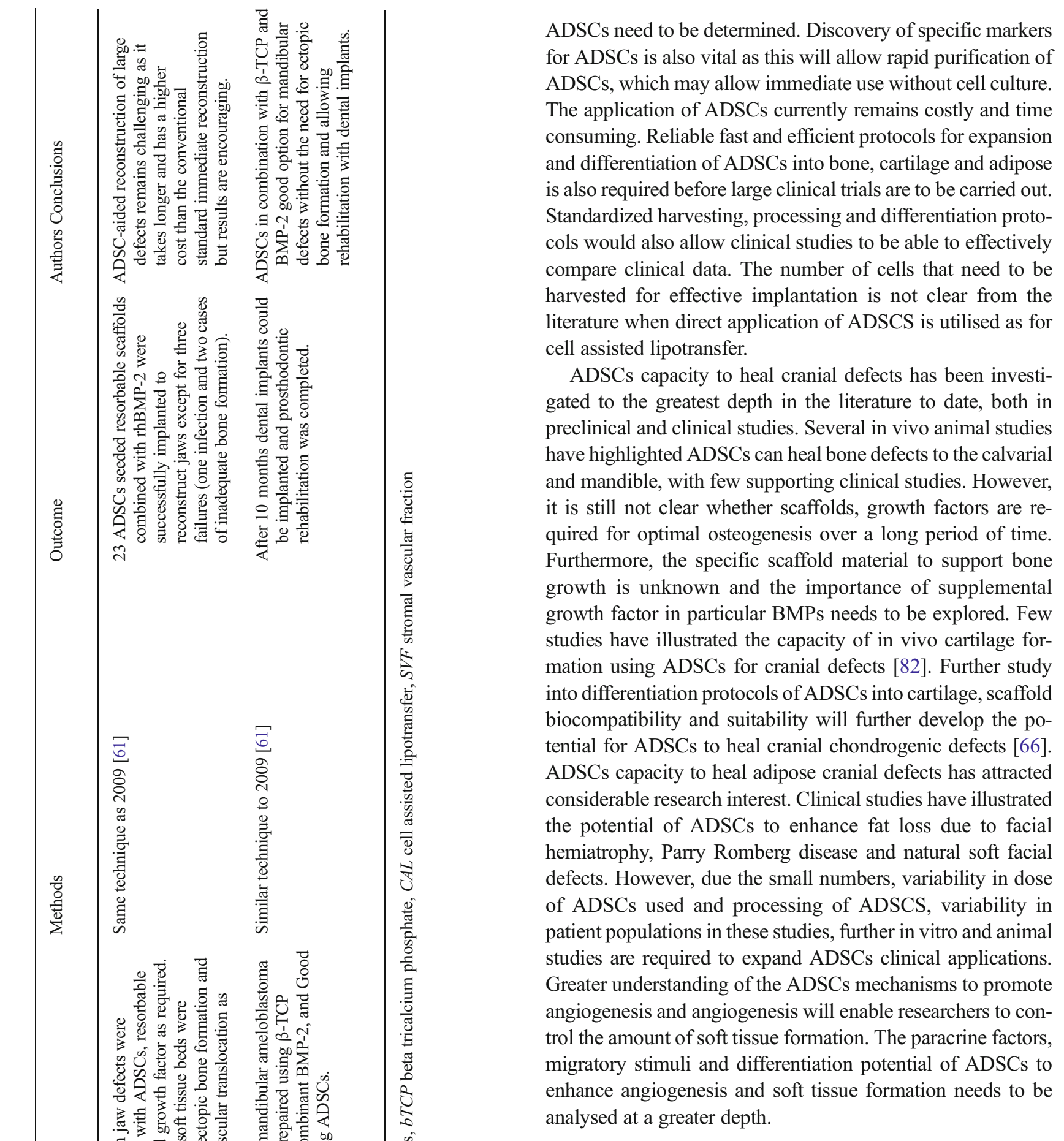

\section{Conclusion}

Preclinical data and few clinical studies have highlighted the potential of ADSCs for generation of required bone, cartilage and fat tissue for craniofacial surgery. A greater understanding into the mechanisms that control ADSC differentiation, immunodulatory functions and angiogenesis capacity is vital to expand the use of ADSCS in craniofacial surgery. Furthermore the optimal harvesting and processing techniques of 
ADSCs for cultured and uncultured ADSCs needs to be determined. This acquired knowledge will allow surgeons and researchers in the future to control ADSCs in expansion or through direct implantation providing optimal tissue restoration for craniofacial applications. Currently we are working in extraction of ADSCs in frametime of an operation of 2$3 \mathrm{~h}$, which may reduce the regulatory hurdle in the future.

\section{Acknowledgments None \\ Conflict of Interest None}

Open Access This article is distributed under the terms of the Creative Commons Attribution License which permits any use, distribution, and reproduction in any medium, provided the original author(s) and the source are credited.

\section{References}

1. Jin, H. J., Bae, Y. K., Kim, M., et al. (2013). Comparative analysis of human mesenchymal stem cells from bone marrow, adipose tissue, and umbilical cord blood as sources of cell therapy. International Journal of Molecular Sciences, 3(14), 17986-18001.

2. Zuk, P. A., Zhu, M., Mizuno, H., et al. (2001). Multilineage cells from human adipose tissue: implications for cell-based therapies. Tissue Engineering, 7, 211-228.

3. Tanikawa, D. Y., Aguena, M., Bueno, D. F., Passos-Bueno, M. R., \& Alonso, N. (2013). Fat grafts supplemented with adipose-derived stromal cells in the rehabilitation of patients with craniofacial microsomia. Plastic and Reconstructive Surgery, 132, 141-152.

4. Kim, M., Kim, I., Lee, S. K., Bang, S. I., \& Lim, S. Y. (2011). Clinical trial of autologous differentiated adipocytes from stem cells derived from human adipose tissue. Dermatologic Surgery, 37, 750-759.

5. Yong Lee, W., Joo Park, K., Beom Cho, Y., et al. (2013). Autologous adipose tissue-derived stem cells treatment demonstrated favorable and sustainable therapeutic effect for crohn's fistula. Stem Cells, 31, 2575-2581.

6. Smith, D. M., Afifi, A. M., Cooper, G. M., Mooney, M. P., Marra, K. G., \& Losee, J. E. (2008). BMP-2-based repair of large-scale calvarial defects in an experimental model: regenerative surgery in cranioplasty. Journal Craniofacial Surgery, 19, 1315-1322.

7. Lipa, J. E., \& Butler, C. E. (2004). Enhancing the outcome of free latissimus dorsi muscle flap reconstruction of scalp defects. Head \& Neck, 26, 46-53.

8. Chen, Z., Zhang, W., Huang, J., Ren, J., \& Zhu, Y. (2011). Exceedingly expanded retroauricular flaps for microtia reconstruction. Journal of Plastic, Reconstructive \& Aesthetic Surgery, 64, 1448-1453.

9. Wellisz, T. (1993). Clinical experience with the Medpor porous polyethylene implant. Aesthetic Plastic Surgery, 17, 339-344.

10. Sevin, K., Askar, I., Saray, A., \& Yormuk, E. (2000). Exposure of high-density porous polyethylene (Medpor) used for contour restoration and treatment. British Journal Oral Maxillofacial Surgery, 38, 44-49.

11. Cenzi, R., Farina, A., Zuccarino, L., \& Carinci, F. (2005). Clinical outcome of 285 Medpor grafts used for craniofacial reconstruction. The Journal of Craniofacial Surgery, 16, 526-530.

12. Shanbhag, A., Friedman, H. I., Augustine, J., \& von Recum, A. F. (1990). Evaluation of porous polyethylene for external ear reconstruction. Annals of Plastic Surgery, 24, 32-39.
13. Nayyer, L., Birchall, M., Seifalian, A. M., \& Jell, G. (2013). Design and development of nanocomposite scaffolds for auricular reconstruction. Nanomedicine, 10, 235-246.

14. Yoshimura, K., Suga, H., \& Eto, H. (2009). Adipose-derived stem/progenitor cells: Roles in adipose tissue remodeling and potential use for soft tissue augmentation. Regenerative Medicine, 4, 265-273.

15. Suga, H., Matsumoto, D., \& Inoue, K. (2008). Numerical measurement of viable and nonviable adipocytes and other culular components in aspirated fat tissue. Plastic and Reconstructive Surgery, 122, 103-114.

16. Bunnell, B. A., Flaat, M., Gagliardi, C., Patel, B., \& Ripoll, C. (2008). Adipose-derived stem cells: isolation, expansion and differentiation. Methods, 45, 115-120.

17. Gnanasegaran, N., Govindasamy, V., Musa, S., \& Kasim, N. H. (2014). Different isolation methods alter the gene expression profiling of adipose derived stem cells. International Journal of Medical Sciences, 11, 391-403.

18. Markarian, C. F., Frey, G. Z., Silveira, M. D., Chem, E. M., Milani, A. R., Ely, P. B., Horn, A. P., Nardi, N. B., \& Camassola, M. (2014). Isolation of adipose-derived stem cells: a comparison among different methods. Biotechnology Letters, 36, 693-702.

19. Zhu, M., Heydarkhan-Hagvall, S., Hedrick, M., Benhaim, P., \& Zuk, P. (2013). Manual isolation of adipose-derived stem cells from human lipoaspirates. Journal of Visualized Experiments, 26, e50585.

20. Gronthos, S., \& Zannettino, A. C. (2011). Methods for the purification and characterization of human adipose-derived stem cells. Methods in Molecular Biology, 702,109-120.

21. Pu, L. L., Coleman, S. R., Cui, X., Ferguson, R. E., Jr., \& Vasconez, H. C. (2008). Autologous fat grafts harvested and refined by the Coleman technique: a comparative study. Plastic and Reconstructive Surgery, 122, 932-937.

22. Rose, J. G., Jr., Lucarelli, M. J., Lemke, B. N., Dortzbach, R. K., Boxrud, C. A., Obagi, S., et al. (2006). Histologic comparison of autologous fat processing methods. Ophthalmic Plastic and Reconstructive Surgery, 22, 195-200.

23. Condé-Green, A., de Amorim, N. F., \& Pitanguy, I. (2010). Influence of decantation, washing and centrifugation on adipocyte and mesenchymal stem cell content of aspirated adipose tissue: a comparative study. Journal of Plastic, Reconstructive \& Aesthetic Surgery, 63, 1375-1381.

24. Pulsfort, A. K., Wolter, T. P., \& Pallua, N. (2011). The effect of centrifugal forces on viability of adipocytes in centrifuged lipoaspirates. Annals of Plastic Surgery, 66, 292-295.

25. Condé-Green, A., Baptista, L. S., de Amorin, N. F., et al. (2010). Effects of centrifugation on cell composition and viability of aspirated adipose tissue processed for transplantation. Aesthetic Surgery Journal, 30, 249-255.

26. Reshak, A. H., Shahimin, M. M., \& Buang, F. (2013). Comparative study on human and bovine AT-SC isolation methods. Progress in Biophysics \& Molecular biology, 113, 295-298.

27. Araña, M., Mazo, M., Aranda, P., Pelacho, B., \& Prosper, F. (2013). Adipose tissue-derived mesenchymal stem cells: isolation, expansion, and characterization. Methods in Molecular Biology, 1036, 47-61.

28. Bray, G. A. (2004). Medical consequences of obesity, Journal of Clinical Endocrinology and Metabolism, 89, 2583.

29. Mitchell, J. B. M. K., Zvonic, S., Garrett, S., et al. (2006). The immunophenotype of human adipose derived cells: Temporal changes in stromal- and stem cell-associated markers. Stem Cells, 24, 376-385.

30. Kondo, K., Shintani, S., Shibata, R., Murakami, H., Murakami, R., Imaizumi, T., et al. (2009). Implantation of adipose-derived regenerative cells enhances ischemia induced angiogenesis. Arteriosclerosis, Thrombosis, and Vascular Biology, 29, 61-66.

31. Sumi, M., Sata, M., Toya, N., Yanaga, K., Ohki, T., \& Nagai, R. (2007). Transplantation of adipose stromal cells, but not mature adipocytes, augments ischemia-induced angiogenesis. Life Sciences, $80,559-565$. 
32. Takami, Y., Kikuchi, Y., Saito, Y., Tamai, K., Ogihara, T., \& Kaneda, Y. (2005). Novel autologous cell therapy in ischemic limb disease through growth factor secretion by cultured adipose tissuederived stromal cells. Arteriosclerosis, Thrombosis, and Vascular Biology, 25, 2542-2547.

33. M, Tamarat R, Clergue M, Manneville C, Saillan-Barreau C, Duriez M, Tedgui A, Levy B, Pénicaud L, Casteilla L. (2004). Plasticity of human adipose lineage cells toward endothelial cells: physiological and therapeutic perspectives. Circulation, 109, 656-63.

34. Harada, Y., Yamamoto, Y., Tsujimoto, S., Matsugami, H., Yoshida, A., \& Hisatome, I. (2013). Transplantation of freshly isolated adipose tissue-derived regenerative cells enhances angiogenesis in a murine model of hind limb ischemia. Biomedical Research, 34, 23-29.

35. Zografou, A., Papadopoulos, O., Tsigris, C., et al. (2013). Autologous transplantation of adipose-derived stem cells enhances skin graft survival and wound healing in diabetic rats. Annals of Plastic Surgery, 71, 225-232.

36. Sheng, L., Yang, M., Liang, Y., \& Li, Q. (2013). Adipose tissuederived stem cells (ADSCs) transplantation promotes regeneration of expanded skin using a tissue expansion model. Wound Repair and Regeneration, 21, 746-754

37. Huang, S. P., Huang, C. H., Shyu, J. F., et al. (2013). Promotion of wound healing using adipose-derived stem cells in radiation ulcer of a rat model. Journal of Biomedical Science, 20(51), 22.

38. Jiang, D., Qi, Y., Walker, N. G., et al. (2013). The effect of adipose tissue derived MSCs delivered by a chemically defined carrier on fullthickness cutaneous wound healing. Biomaterials, 34, 2501-2515.

39. Lin, Y. C., Grahovac, T., Oh, S. J., Ieraci, M., Rubin, J. P., \& Marra, K. G. (2013). Evaluation of a multi-layer adipose-derived stem cell sheet in a full-thickness wound healing model. Acta Biomaterialia, 9, 5243-5250

40. Choi, E. W., Shin, I. S., Park, S. Y., et al. (2012). Reversal of serologic, immunologic, and histologic dysfunction in mice with systemic lupus erythematosus by long-term serial adipose tissuederived mesenchymal stem cell transplantation. Arthritis and Rheumatism, 64, 243-253.

41. ter Huurne, M., Schelbergen, R., Blattes, R., et al. (2012). Antiinflammatory and chondroprotective effects of intraarticular injection of adipose-derived stem cells in experimental osteoarthritis. Arthritis and Rheumatism, 64, 3604-3613.

42. Kang, J. W., Kang, K. S., Koo, H. C., Park, J. R., Choi, E. W., \& Park, Y. H. (2008). Soluble factors-mediated immunomodulatory effects of canine adipose tissue-derived mesenchymal stem cells. Stem Cells and Development, 17, 681-693.

43. Yañez, R., Oviedo, A., Aldea, M., Bueren, J. A., \& Lamana, M. L. (2010). Prostaglandin E2 plays a key role in the immunosuppressive properties of adipose and bone marrow tissue-derived mesenchymal stromal cells. Experimental Cell Research, 316, 3109-3123.

44. Yañez, R., Lamana, M. L., García-Castro, J., Colmenero, I., Ramírez, M., \& Bueren, J. A. (2006). Adipose tissue-derived mesenchymal stem cells have in vivo immunosuppressive properties applicable for the control of the graft-versus-host disease. Stem Cells, 24, 2582-2591.

45. Guasti, L., Vagaska, B., Bulstrode, N. W., Seifalian, A. M., \& Ferretti, P. (2013). Chondrogenic differentiation of adipose tissuederived stem cells within nanocaged POSS-PCU scaffolds: A new tool for nanomedicine. Nanomedicine, 10, 279-289.

46. Mahmoudifar, N., \& Doran, P. M. (2013). Osteogenic differentiation and osteochondral tissue engineering using human adiposederived stem cells. Biotechnology Progress, 29, 176-185.

47. Silva, A. R., Paula, A. C., Martins, T. M., Goes, A. M., \& Pereria, M. M. (2013). Synergistic effect between bioactive glass foam and a perfusion bioreactor on osteogenic differentiation of human adipose stem cells. Journal of Biomedical Materials Research. Part A, 102, 818-827.

48. Choi, J. W., Park, E. J., Shin, H. S., Shin, I. S., Ra, J. C., \& Koh, K. S. (2012). In Vivo Differentiation of Undifferentiated Human Adipose
Tissue-Derived Mesenchymal Stem Cells in Critical-Sized Calvarial Bone Defects. Annals of Plastic Surgery, 72, 225-233.

49. Di Bella, C., Farlie, P., \& Penington, A. J. (2008). Bone regeneration in a rabbit critical-sized skull defect using autologous adiposederived cells. Tissue Engineering. Part A, 14, 483-490.

50. Liu, G., Zhang, Y., Liu, B., Sun, J., Li, W., \& Cui, L. (2013). Bone regeneration in a canine cranial model using allogeneic adipose derived stem cells and coral scaffold. Biomaterials, 34, 2655-2664.

51. Rapp SJ, Jones DC, Gerety P, Taylor JA. (2012). Repairing criticalsized rat calvarial defects with progenitor cell-seeded acellular periosteum: a novel biomimetic scaffold. Surgery, 152, 595-604, 605.e1; discussion 604-5.

52. Lin, Y., Tang, W., Wu, L., et al. (2008). Bone regeneration by BMP2 enhanced adipose stem cells loading on alginate gel. Histochemistry and Cell Biology, 129, 203-210.

53. Lin, L., Shen, Q., Wei, X., et al. (2009). Comparison of osteogenic potentials of BMP4 transduced stem cells from autologous bone marrow and fat tissue in a rabbit model of calvarial defects. Calcified Tissue International, 85, 55-65.

54. Thesleff, T., Lehtimäki, K., Niskakangas, T., et al. (2011). Cranioplasty with adipose-derived stem cells and biomaterial: a novel method for cranial reconstruction. Neurosurgery, 68, 1535-1540.

55. Lendeckel, S., Jödicke, A., Christophis, P., et al. (2004). Autologous stem cells (adipose) and fibrin glue used to treat widespread traumatic calvarial defects: case report. Journal of Cranio-MaxilloFacial Surgery, 32, 370-373.

56. Wilson, S. M., Goldwasser, M. S., Clark, S. G., et al. (2012). Adipose-derived mesenchymal stem cells enhance healing of mandibular defects in the ramus of swine. Journal of Oral and Maxillofacial Surgery, 70, e193-e203.

57. Haghighat, A., Akhavan, A., Hashemi-Beni, B., Deihimi, P., Yadegari, A., \& Heidari, F. (2011). Adipose derived stem cells for treatment of mandibular bone defects: An autologous study in dogs. Dental Research Journal(Isfahan), 8(Suppl 1), S51-S57.

58. Sándor, G. K. (2012). Tissue engineering of bone: Clinical observations with adipose-derived stem cells, resorbable scaffolds, and growth factors. Annual Maxillofacial Surgery, 2, 8-11.

59. Sándor, G. K., Tuovinen, V. J., Wolff, J., et al. (2013). Adipose stem cell tissue-engineered construct used to treat large anterior mandibular defect: a case report and review of the clinical application of good manufacturing practice-level adipose stem cells for bone regeneration. Journal of Oral and Maxillofacial Surgery, 71, 938-950.

60. Taylor, J. A. (2010). Bilateral orbitozygomatic reconstruction with tissue-engineered bone. The Journal of Craniofacial Surgery, 21, $1612-1614$.

61. Mesimäki, K., Lindroos, B., Törnwall, J., Mauno, J., Lindqvist, C., Kontio, R., et al. (2009). Novel maxillary reconstruction with ectopic bone formation by GMP adipose stem cells. International Journal of Oral and Maxillofacial Surgery, 38, 201-209.

62. Adelola O. Oseni, C Crowley, MZ. Boland, PE Butler and AM. Seifalian Cartilage Tissue Engineering: the Application of Nanomaterials and Stem Cell Technology. Eberli D. (2011). In Tissue Engineering for Tissue and Organ Regeneration. In Tech. CC BY-NC-SA 3.0 license, 233-266

63. Cao, Y., Vacanti, J. P., Paige, K. T., Upton, J., \& Vacanti, C. A. (1997). Transplantation of chondrocytes utilizing a polymer-cell construct to produce tissue-engineered cartilage in the shape of a human ear. Plast. Reconstructive Surgery, 100, 297-307.

64. Denker, A. E., Nicoll, S. B., \& Tuan, R. S. (1995). Formation of cartilage-like spheroids by micromass cultures of murine C3H10T1/ 2 cells upon treatment with transforming growth factor-beta 1 . Differentiation, 59, 25-34.

65. Yoon, I. S., Chung, C. W., Sung, J. H., et al. (2011). Proliferation and chondrogenic differentiation of human adipose-derived mesenchymal stem cells in porous hyaluronic acid scaffold. Journal of Bioscience and Bioengineering, 112, 402-408. 
66. Puetzer, J. L., Petitte, J. N., \& Loboa, E. G. (2010). Comparative review of growth factors for induction of three-dimensional in vitro chondrogenesis in human mesenchymal stem cells isolated from bone marrow and adipose tissue. Tissue Engineering. Part B, Reviews, 16, 435-444.

67. Erickson, G. R., Gimble, J. M., Franklin, D. M., Rice, H. E., Awad, H., \& Guilak, F. (2002). Chondrogenic potential of adipose tissuederived stromal cells in vitro and in vivo. Biochemical and Biophysical Research Communications, 290, 763-769.

68. Awad, H. A., Halvorsen, Y. D., Gimble, J. M., \& Guilak, F. (2003). Effects of transforming growth factor beta1 and dexamethasone on the growth and chondrogenic differentiation of adipose-derived stromal cells. Tissue Engineering, 9, 1301-1312.

69. Awad, H. A., Wickham, M. Q., Leddy, H. A., Gimble, J. M., \& Guilak, F. (2004). Chondrogenic differentiation of adipose derived adult stem cells in agarose, alginate, and gelatin scaffolds. Biomaterials, 25, 3211-3222.

70. Huang, J. I., Zuk, P. A., Jones, N. F., Zhu, M., Lorenz, H. P., Hedrick, M. H., et al. (2004). Chondrogenic potential of multipotential cells from human adipose tissue. Plastic and Reconstructive Surgery, 113, 585-595.

71. Betre, H., Ong, S. R., Guilak, F., Chilkoti, A., Fermor, B., \& Setton, L. A. (2006). Chondrocytic differentiation of human adipose derived adult stem cells in elastin-like polypeptide. Biomaterials, 27, 91-99.

72. Estes, B. T., Wu, A. W., \& Guilak, F. (2006). Potent induction of chondrocytic differentiation of human adipose-derived adult stem cells by bone morphogenetic protein 6 . Arthritis and Rheumatism, $54,1222-1232$.

73. Wei, Y., Hu, Y., Lv, R., \& Li, D. (2006). Regulation of adipose derived adult stem cells differentiating into chondrocytes with the use of rhBMP-2. Cytotherapy, 8, 570-579.

74. Mehlhorn, A. T., \& Niemeyer, P. K. (2007). Differential effects of BMP-2 and TGF-beta 1 on chondrogenic differentiation of adipose derived stem cells. Cell Proliferation, 40, 809-823.

75. Kim, H. J., \& Im, G. I. (2009). Combination of transforming growth factor-beta2 and bone morphogenetic protein 7 enhances chondrogenesis from adipose tissue-derived mesenchymal stem cells. Tissue Engineering. Part A, 15, 1543-1551.

76. Dragoo, J. L., Carlson, G., McCormick, F., et al. (2007). Healing full-thickness cartilage defects using adipose-derived stem cells. Tissue Engineering, 13, 1615-1621.

77. Leslie, S. K., Cohen, D. J., Sedlaczek, J., Pinsker, E. J., Boyan, B. D., \& Schwartz, Z. (2013). Controlled release of rat adipose-derived stem cells from alginate microbeads. Biomaterials, 34, 8172-8184.

78. Cui, L., Wu, Y., Cen, L., et al. (2009). Repair of articular cartilage defect in non-weight bearing areas using adipose derived stem cells loaded polyglycolic acid mesh. Biomaterials, 30, 2683-2693.

79. Mehlhorn, A. T., Zwingmann, J., Finkenzeller, G., et al. (2009). Chondrogenesis of adipose-derived adult stem cells in a polylactide-co-glycolide scaffold. Tissue Engineering. Part A, 15, 1159-1167.

80. Liu, J., Zhao, B., Zhang, Y., Lin, Y., Hu, P., \& Ye, C. (2010). PHBV and predifferentiated human adipose-derived stem cells for cartilage tissue engineering. Journal of Biomedical Materials Research. Part A, 94, 603-610.

81. Lin, Y., Luo, E., Chen, X., et al. (2005). Molecular and cellular characterization during chondrogenic differentiation of adipose tissue-derived stromal cells in vitro and cartilage formation in vivo. Journal of Cellular and Molecular Medicine, 9, 929-939.

82. Bahrani, H., Razmkhah, M., Ashraf, M. J., Tanideh, N., Chenari, N., Khademi, B., et al. (2012). Differentiation of adipose-derived stem cells into ear auricle cartilage in rabbits. Journal of Laryngology and Otology, 126, 770-774.

83. Neuber, G. A. (1893). Verhandlungen der Deutschen Gesellschaftfür. Chirurgie, 1, 66.

84. Yoshimura, K., Sato, K., Aoi, N., et al. (2008). Cell-assisted lipotransfer for facial lipoatrophy: efficacy of clinical use of adipose-derived stem cells. Dermatologic Surgery, 34, 1178-1185.
85. Yoshimura K1, Eto H, Kato H, Doi K, Aoi N. (2011). In vivo manipulation of stem cells for adipose tissue repair/reconstruction. Regen Med, 6, 33-41.

86. Aiba-Kojima, E., Tsuno, N. H., Inoue, K., et al. (2007). Characterization of wound drainage fluids as a source of soluble factors associated with wound healing: comparison with plateletrich plasma and potential use in cell culture. Wound Repair and Regeneration, 15, 511-520.

87. Muthukrishnan, L., Warder, E., \& McNeil, P. L. (1991). Basic fibroblast growth factor is efficiently released from a cytolsolic storage site through plasma membrane disruptions of endothelial cells. Journal of Cellular Physiology, 148, 1-16.

88. Suga, H., Eto, H., Aoi, N., et al. (2010). Adipose tissue remodeling under ischemia: death of adipocytes and activation of stem/progenitor cells. Plastic and Reconstructive Surgery, 126, 1911-1923.

89. Soulez, M., Sirois, I., Brassard, N., et al. (2010). Epidermal growth factor and perlecan fragments produced by apoptotic endothelial cells co-ordinately activate ERK1/2- dependent antiapoptotic pathways in mesenchymal stem cells. Stem Cells, 28, 810-820.

90. Myolotte, L. A., Duffy, A. M., Murphy, M., et al. (2008). Metabolic flexibility permits mesenchymal stem cell survival in an ischemic environment. Stem Cells, 26, 1325-1336.

91. Zhu, M., Zhou, Z., Chen, Y., et al. (2010). Supplementation of fat grafts with adipose-derived regenerative cells improves long-term graft retention. Annals of Plastic Surgery, 64, 222-228.

92. Moseley, T. A., Zhu, M., \& Hedrick, M. H. (2006). Adipose-derived stem and progenitor cells as fillers in plastic and reconstructive surgery. Plastic and Reconstructive Surgery, 118, 121S-128S.

93. Matsumoto, D., Sato, K., Gonda, K., et al. (2006). Cell-assisted lipotransfer: supportive use of human adipose-derived cells for soft tissue augmentation with lipoinjection. Tissue Engineering, 12, 3375-3382.

94. Lu, F., Li, J., Gao, J., et al. (2009). Improvement of the survival of human autologous fat transplantation by using VEGF-transfected adipose-derived stem cells. Plastic and Reconstructive Surgery, 124, 1437-1446.

95. Venugopal, B., Fernandez, F. B., Babu, S. S., Harikrishnan, V. S., Varma, H., \& John, A. (2012). Adipogenesis on biphasic calcium phosphate using rat adipose-derived me senchymal stem cells: in vitro and in vivo. Journal of Biomedical Materials Research. Part A, 100, 1427-1437.

96. Morgan, S. M., Ainsworth, B. J., Kanczler, J. M., Babister, J. C., Chaudhuri, J. B., \& Oreffo, R. O. (2009). Formation of a humanderived fat tissue layer in $\mathrm{P}(\mathrm{DL}) \mathrm{LGA}$ hollow fibre scaffolds for adipocyte tissue engineering. Biomaterials, 30, 1910-1917.

97. Lee, S. K., Kim, D. W., Dhong, E. S., Park, S. H., \& Yoon, E. S. (2012). Facial Soft Tissue Augmentation using Autologous Fat Mixed with Stromal Vascular Fraction. Archivial Plastic Surgery, 39, 534-539.

98. Castro-Govea, Y., De La Garza-Pineda, O., Lara-Arias, J., et al. (2012). Cell-assisted lipotransfer for the treatment of parry-romberg syndrome. Archivial Plastic Surgery, 39, 659-662.

99. Karaaltin, M. V., Akpinar, A. C., Baghaki, S., \& Akpinar, F. (2012). Treatment of "en coup de sabre" deformity with adipose-derived regenerative cell-enriched fat graft. The Journal of Craniofacial Surgery, 23, e103-e105.

100. Koh, K. S., Oh, T. S., Kim, H., et al. (2012). Clinical application of human adipose tissue-derived mesenchymal stem cells in progressive hemifacial atrophy (Parry-Romberg disease) with microfat grafting techniques using 3-dimensional computed tomography and 3dimensional camera. Annals of Plastic Surgery, 69, 331-337.

101. Tanikawa, D. Y., Aguena, M., Bueno, D. F., Passos-Bueno, M. R., \& Alonso, N. (2013). Fat grafts supplemented with adipose-derived stromal cells in the rehabilitation of patients with craniofacial microsomia. Plastic and Reconstructive Surgery, 132, 141-152.

102. Li, J., Gao, J., Cha, P., et al. (2013). Supplementing fat grafts with adipose stromal cells for cosmetic facial contouring. Dermatologic Surgery, 39(3 Pt 1), 449-456. 